\title{
HISTORY OF DISCOVERY AND TYPIFICATION OF GALIUM CRACOVIENSE (RUBIACEAE)
}

\author{
ZBIGNIEW SZELĄG
}

Zbigniew Szelag, Institute of Botany, Jagiellonian University, Kopernika 31, 31-501 Kraków, Poland; e-mail: azszelag@wp.pl

Galium cracoviense Ehrend., an endemic species of the Polish flora, grows on the some Jurassic hills near Olsztyn in the Wyżyna KrakowskoCzęstochowska upland (Cieślak \& Szeląg 2009). This name is lectotypified by a specimen of G. silvestre var. microphyllum $\mathrm{R}$. Uechtr. collected by Baumann in 1864 and stored at the herbarium of the Institute of Botany Jagiellonian University, Kraków (KRA).

\section{Galium cracoviense Ehrend.}

Fig. 1

Sitzungsber. Oesterr. Akad. Wiss., Math.-Nat., Abt. 1. 169: 419. 1960 - G. silvestre var. microphyllum $\mathrm{R}$. Uechtr., Bot. Zeitung 32: 206. 1874 - TYPE LOCALITY: 'Olsztyn im südwestlichsten Polen (leg. Baumann, Karo)' - LECTOTYPE (designated here): Kalkfelsen der Ruine Olsztyn im südwestl. Rus. Polen, Sept. 1864, Baumann (ex herb. R. Uechtritz), KRA 242023 - ORIGINAL MATERIAL: Na skałach w Olsztynie pod Częstochową, 1865, F. Karo, KRA 242024.

- G. silvestre var. polonica Rostafiński 1873, in schedis

In the Polish literature, Ferdynand Karo (1845$1927)$ is regarded as discoverer of $G$. cracoviense (Hereźniak 2004); he carried out floristic studies in the vicinity of Częstochowa in 1874-1880 (Karo 1881). However, herbarium material serving as a basis for description of $G$. silvestre var. microphyllum had been collected also by C. Baumann (†1874), a teacher of the Königliche Katholische Gymnasium, Oppeln (now Opole) (Uechtritz 1874). Karo (1881) does not mention Baumann's discovery, which suggests that he may not have seen the protologue and that he repeated the alleged journal title Hallesche bot. Zeitung (cf. Karo
1881: 230) after the label in Uechtritz's herbarium (in fact the title was Botanische Zeitung and the journal was issued in Leipzig).

Views also differ on the date of discovery of G. cracoviense by Karo, who wrote in his Flora okolic Czestochowy (Flora of the Częstochowa region): 'I collected it for the first time in 1874' (Karo 1881: 229), while the oldest preserved herbarium specimen he collected is dated 1865. Also on the label of the G. cracoviense specimen (WA19385) collected on 12 June 1878 is Karo's handwritten statement: 'Skały w Olsztynie 1865 odkryłem' ('Rocks in Olsztyn 1865, I discovered').

In KRA, original material of $G$. silvestre var. microphyllum is deposited, obtained by Irena $\mathrm{Ku}$ cowa during her studies (Kucowa 1962). Among them is a specimen from Uechtritz's herbarium, with his own note, collected by Baumann in 1864, that is, a year before Karo's discovery (Fig. 1).

In 1873 the species was collected on rocks in Olsztyn also by Józef Rostafiński, who named it $G$. silvestre var. polonica, but he did not publish this name.

Raising G. silvestre var. microphyllum to species level, Ehrendorfer (1960) had to create a new name for it. Therefore claims that Ehrendorfer described G. cracoviense based on herbarium material courteously lent to him (Kucowa 1962) are not legitimate, and Hereźniak's (2004) discussion of a 'not wellchosen' specific epithet also apply to that case.

ACKNOWLEDGEMENTS: I am grateful to Dr. Maja Graniszewska (WA) and Dr. Małgorzata Jaźwa (KRA) for photographing Karo's specimens, and to the anonymous reviewer for valuable remarks on the manuscript. 


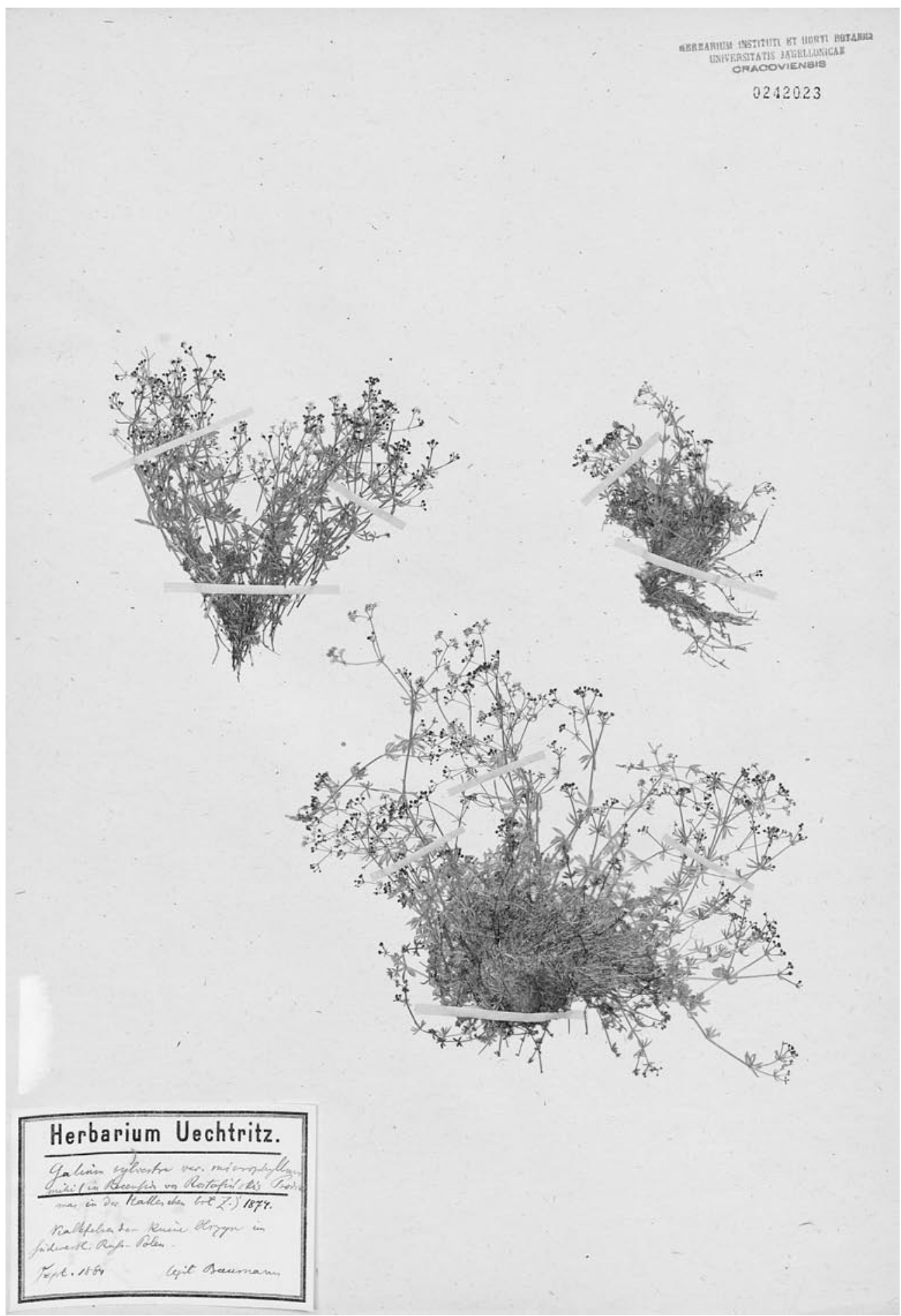

Fig. 1. Lectotype of Galium cracoviense Ehrend. 


\section{REFERENCES}

CieŚlak E. \& Szeląg Z. 2009. Genetic diversity of Galium cracoviense (Rubiaceae) the Polish endemic plant. Acta Soc. Bot. Poloniae 78: 123-129.

EHRENDORFER F. 1960. Neufassung der Sektion Lepto-Galium Lange und Beschreibung neuer Arten und Kombinationen. (Zur Phylogenie der Gattung Galium, VII.). Sitzungsberichten der Oesterr. Akademie der Wissenschaften, Mathem.naturw. Kl., Abt. I 169(9/10): 407-421.

Karo F. 1881. Flora okolic Częstochowy. Pamiętnik Fizjograficzny 1: 208-257.
KUCOWA I. 1962. Species of the genus Galium L. of the section Leptogalium Lange found in Poland and neighbouring territories. Fragm. Florist. Geobot. 8: 417-442 (in Polish with English summary).

HereźNIAK J. 2004. Ferdynand Karo (1845-1927) pharmacist, outstanding forgotten researcher of Polish and Siberian flora. In: J. PARTYKA (ed.), The diversification and transformation of natural and cultural environment of the Kraków-Częstochowa upland. 2: 315-322. Ojcowski Park Narodowy, Ojców (in Polish with English summary).

UECHTRITZ R. V. 1874. Galium silvestre var. microphyllum Uechtritz. Botanische Zeitung 23: 206-207.

\section{Received 16 March 2013}

